\title{
SEROPREVALENCE OF HUMAN IMMUNODEFICIENCY VIRUS INFECTION IN PREGNANCY IN A TERTIARY CARE HOSPITAL
}

\author{
PAWAN M. UKEY, SURESH L. AKULWAR*, RAJARAM M. POWAR
}

\section{ABSTRACT}

BACKGROUND: Human Immunodeficiency Virus (HIV) /Acquired Immunodeficiency Syndrome (AIDS) is increasing at an alarming rate globally. It has now become a major challenge \& threat to public health. HIV infection in women occur primarily during their reproductive years, hence pregnancy provides a unique opportunity for implementing prevention strategies against HIV infection. If we estimate seroprevalence in pregnancy, the effective \& timely intervention will reduce the transmission of infection to newborns. AIMS: To study the seroprevalence of HIV infection in pregnancy in a tertiary care hospital. SETTING: Antenatal Care Clinic of a Tertiary Care Hospital. DESIGN: A cross-sectional study. MATERIAL AND METHODS: Blood samples of all the pregnant women with written consent were collected and tested for HIV antibodies as per National AIDS Control Organization (NACO) guidelines over a period from September 2002 to August 2004. However only those who were HIV seroreactive were included in this study. Spouses of seroreactive pregnant women were also counselled and tested. Statistical analysis was done using Chi-square test. RESULTS: Out of the total 10683 blood samples from pregnant women tested, 147 (1.38\%) were found to be HIV seroreactive. Seroreactive cases when compiled year-wise, showed increase in the seroprevalence from 1.24\% in September 2002 - August 2003 to $1.45 \%$ in September 2003 - August 2004. Majority 69 (46.94\%) seroreactive pregnant women were in the age group of 19-24 years followed by 25-29 years age group (31.29\%). Out of 88 spouses of HIV seroreactive pregnant women, 85 (96.59\%) were found to be HIV seroreactive. CONCLUSION: In the present study, seroprevalence of HIV infection was found to be $1.38 \%$ amongst pregnant women.

KEY WORDS : Seroprevalence., Human Immunodeficiency Virus (HIV) antibodies, Pregnant Women.

\section{INTRODUCTION}

Dept. of Microbiology, Lecturer,

Dept. of Microbiology, *Associate Professor,

Professor and Head

Correspondence

Suresh L. Akulwar*

Dept. of Microbiology, Govt. Medical College, Nagpur-03

E-mail: pawan_ukey@rediffmail.com
Since the Human immunodeficiency virus (HIV) / Acquired immunodeficiency syndrome (AIDS) epidemic began, almost 58 million people throughout the world have been infected with HIV and almost 22 million people have died due to the disease. ${ }^{[1]}$ AIDS has shifted its epicenter from Africa to Asia and is 
no longer a predominantly male epidemic. ${ }^{[2]}$ In India, the estimated number of adults and children living with HIV/AIDS at the end of 2003 is 5.1 million and cumulative AIDS cases in female are 23978. ${ }^{[3]}$ Heterosexual transmission is by far the most common route for contracting HIV infection in India. ${ }^{[4,5]}$ HIV infection among female commercial sex workers in certain areas is rising. ${ }^{[2]}$ But prevalence in this group does not reflect the prevalence of general population. Prevalence of HIV in pregnancy would indicate the HIV prevalence in female population and to some extent in general population. Mother to child transmission is by far the most significant route of transmission of HIV infection in children below the age of 15 years. ${ }^{[6]}$ The transmission may occur late in pregnancy, during labour and delivery ${ }^{[7]}$ and through breast milk. ${ }^{[8]}$ Definite cure for HIV is still far from reach but prevention of further spread of disease is in our hands. As HIV infection in women occur primarily during their reproductive years, pregnancy provides a unique opportunity for implementing HIV infection prevention strategies in women. ${ }^{[9]}$ If we estimate seroprevalence in pregnancy, the effective \& timely intervention will reduce the transmission of infection to newborn babies.

Hence, the study was planned to determine the seroprevalence of HIV infection in pregnant women attending Antenatal Care (ANC) Clinic of a Tertiary Care Hospital.

\section{MATERIAL AND METHODS}

All pregnant women attending ANC Clinic of a Tertiary Care Hospital for obstetric consultation and those coming directly to the labour ward for delivery were counselled for HIV testing. Informed and written consent was obtained. Blood samples from all the pregnant women were collected for HIV testing over a period from September 2002 to August 2004 Samples were processed for HIV antibodies in dept. of Microbiology, as per NACO guidelines. ${ }^{[10]}$ First test was performed using COMBAIDS test, (Span-Diagnostics Ltd. Surat, India). Samples found positive by COMBAIDS were tested by NEVAELISA test (Cadila Pharmaceuticals, Gujarat, India) and SDBIOLINE test, (Standard Diagnostic Inc. Korea)..$^{[1]}$

Only the cases found reactive with above three tests were included in this study (WHO STRATEGY III). The women were asked about their age, awareness regarding AIDS, personal habits, safer sex methods, blood transfusion, drug abuse etc. Spouses of seroreactive pregnant women were also counselled and tested for HIV antibodies as above after obtaining written consent. Reports were issued only after post-test counselling. Strict confidentiality was maintained. Statistical analysis was done using Chi-square test.

\section{RESULTS}

A total of 10683 pregnant women attending antenatal clinic were enlisted and tested for HIV antibodies. Of which, 147 (1.38\%) were found to be HIV seroreactive. During a period of first year, from September 2002 to August 2003, 3640 blood samples were tested, out of which, 45(1.24\%) were found to be HIV seroreactive. During the period of second year, from September 2003 to August 2004, 7043 blood samples were tested, of which,
102(1.45\%) were HIV seroreactive. (Table-1). Statistical analysis was done using Chi-square test; $p$ value was more than 0.05 , which was nonsignificant.

$69(46.94 \%)$ i.e. majority of seroreactive women were in the age group of 19-24 years followed by 25-29 years age group 46 $(31.29 \%)$. In the age group of $30-34$ years, $27(18.37 \%)$ women were found to be HIV seroreactive and in 35-39 \& more than 39 years age group $5(3.40 \%)$ were seroreactive. All the HIV seroreactive women were married and living with their spouses. Out of 88 spouses of HIV seroreactive pregnant women, $85(96.59 \%)$ were found to be HIV seroreactive. 143 (97.28\%) women were

Table 1: Month wise distribution of pregnant women and spouses found seroreactive

\begin{tabular}{|c|c|c|c|}
\hline $\begin{array}{r}\text { Month \& year } \\
P r \\
T\end{array}$ & $\begin{array}{l}\text { No. of } \\
\text { Pregnant Women } \\
\text { Tested For HIV } \\
\text { Antibodies }\end{array}$ & $\begin{array}{c}\text { No. of } \\
\text { en Seroreactive } \\
\text { Tregnant Women } \\
\text { Undergone } 3 \text { Tests U }\end{array}$ & $\begin{array}{c}\text { No. of } \\
\text { Serorective } \\
\text { Spouses } \\
\text { ndergone } 3 \text { Tes }\end{array}$ \\
\hline September 2002 & $2 \quad 117$ & 02 & \\
\hline October 2002 & 299 & 05 & 05 \\
\hline November 2002 & 262 & 03 & 02 \\
\hline December 2002 & 230 & 02 & 01 \\
\hline January 2003 & 391 & 07 & \\
\hline $\begin{array}{l}\text { February } 2003 \\
\text { March } 2003\end{array}$ & 336 & 07 & 00 \\
\hline $\begin{array}{l}\text { March } 2003 \\
\text { Arril } 2003\end{array}$ & 384 & 09 & 09 \\
\hline $\begin{array}{l}\text { April } 2003 \\
\text { May } 2003\end{array}$ & $\begin{array}{l}200 \\
-*\end{array}$ & 00 & 04 \\
\hline June 2003 & 444 & 00 & 00 \\
\hline July 2003 & 553 & & 03 \\
\hline August 2003 & & & \\
\hline Subtotal & 3640 & $45(1.24 \%)$ & 30 \\
\hline September 2003 & 630 & 09 & 07 \\
\hline October 2003 & 453 & 07 & 07 \\
\hline November 2003 & & & \\
\hline December 2003 & 330 & 05 & 01 \\
\hline January 2004 & 832 & 07 & 07 \\
\hline February 2004 & 460 & 03 & 02 \\
\hline March 2004 & 581 & 07 & 03 \\
\hline April 2004 & 798 & 11 & 04 \\
\hline May 2004 & 681 & 09 & 09 \\
\hline June 2004 & 838 & 19 & 03 \\
\hline July 2004 & 864 & 17 & 04 \\
\hline August 2004 & 576 & 08 & 08 \\
\hline Subtotal & 7043 & $102(1.45 \%)$ & 55 \\
\hline Total & 10683 & 147 (1.38\%) & 85 \\
\hline
\end{tabular}

having monogamous relationship while 4 $(2.72 \%)$ women had given a history of premarital or extramarital sexual contact.

Of these 147 seroreactive women, $3(2.04 \%)$ had given a history of sexually transmitted diseases (STDs). Two of them were found to be VDRL seroreactive. One $(0.68 \%)$ woman had given a history of blood transfusion in the past. One $(0.68 \%)$ woman was health care worker who had an accidental exposure to needle prick injury with HIV infected patient.

None of the women or their spouses was intravenous drug user. None of the women had clinical features of AIDS. All the seroreactive women were labelled as 'nevirapine barrier' for subsequent prophylaxis and management. Up to August 2004, 71 (48.3\%) deliveries took place in our hospital. All the pregnant women and their babies had received nevirapine. 56 (78.87\%) delivered full term normal baby vaginally and $15(21.13 \%)$ women required a lower segment caesarean section (LSCS). The babies will be subjected to HIV testing at the age of 18 months.

\section{DISCUSSION}

HIV infection unknown in South East Asian region even 15 years ago has now become a major challenge to public health. Transmission of HIV infection from mother to child is a major concern for developed as well as developing countries. ${ }^{[12]}$

In our study, HIV seroprevalence rate was found to be $1.38 \%$ in pregnant women. In India, it ranges from less than $1 \%$ to $5.9 \%$. $[2,13,14,15,16]$ Slightly higher prevalence rate is 
reported in other South East Asian Countries like Thailand (8\%) and Myanmar (7\%). ${ }^{[2]}$ This high prevalence amongst pregnant women reveals the vulnerability of this low risk group to HIV infection.

The seroprevalence of HIV infection showed a rise from $1.24 \%$ during September 2002 August 2003 to $1.45 \%$ during September 2003 - August 2004. Though this difference is statistically not significant, HIV seroprevalence of more than $1 \%$ in pregnancy is alarming for the health authorities, which indicates that more stress should be given on preventive measures.

The efficiency of transmission of HIV from an infected mother to infant ranges from 15\% to $25 \%$ in developed countries and $25 \%$ to $45 \%$ in developing countries. ${ }^{[6]}$ Two third of the transmission occurs late in pregnancy or during labour and delivery. ${ }^{[7]}$ The risk of acquiring infection through breast milk is also documented. ${ }^{\left[{ }^{8]}\right.}$ Rise of HIV infection in women may give rise to increase in pediatric AIDS cases, which may become a major public health problem in coming years. Hence effective interventions are needed which can interrupt such vertical transmission.

In our study HIV infection was highest in the age group $19-24$ years (46.94\%) followed by the $25-29$ years age group (31.29\%). It may be because of the fact that this is the most sexually active group. High prevalence in this group can be considered as forecasting of financial burden as well as loss of youth for the nation.

The most common route of transmission of HIV infection in India is heterosexual. ${ }^{[4,5,6,17,18]}$ In this study majority of seroreactive women had acquired HIV infection from their spouses. $96.59 \%$ spouses were found to be HIV seroreactive. It was not possible to counsell all the spouses of HIV seroreactive pregnant women because many spouses were labourers, Rickshaw pullers belonging to low socio economic status and because of their loss of daily wages they couldn't attend our clinic. Few spouses were not suffering from any symptom or sign as per the history given by their wives. Therefore they didn't realize the importance of attending the clinic for HIV testing. Some pregnant women came directly to labour ward for delivery whose spouses did not attend our clinic.

All HIV seroreactive husbands had given a history of sexual contact with multiple partners and many had a history of relationship with commercial sex workers (CSW).

Several studies have established the association of STDs and HIV infection. ${ }^{[15,17,19]}$ Both ulcerative and nonulcerative STDs are known to enhance HIV transmission. We found 3 women with a history of presence of STDs. Two of them were VDRL seroreactive.

Various workers ${ }^{[20]}$ have documented HIV transmission through blood and its products as well as through accidental needle prick injury in health care workers, which is consistent with our study. In this study, one pregnant woman had received blood transfusions in the past. She might have been accidentally infected as history of other routes of transmission was ruled out.

Nevirapine prophylaxis can definitely reduce the perinatal transmission of HIV. ${ }^{[21,22]}$ For this routine screening of HIV in all women registered in ANC Clinic is advocated. Up to August 2004 , only $48.3 \%$ of mothers and babies received Nevirapine. This is because some women returned to their parent's home in spite of all the efforts of our staff, as it is a custom in many communities of this region, some delivered at home and in private hospitals. Some women have not completed their term, they were in first and second trimester of pregnancy when detected seroreactive.

Women are sexually, economically and biologically more vulnerable to acquire the HIV infection as well as they bear a great responsibility in providing care to HIV infected family members. As prevalence of HIV infection in pregnant women is high and in the absence of protective vaccine, it is important to educate \& aware them about HIV infection in order to safeguard our future generations. Timely detection and effective counselling can prevent further pregnancies and consequent transmission of HIV infection to the offspring.

\section{CONCLUSIONS}

- In this study seroprevalence of HIV infection was found to be $1.38 \%$ amongst pregnant women.

- The age group of 19-29 years was found to be the most affected age group.

- Heterosexuality was the most predominant route of HIV transmission.

\section{REFERENCES}

1. Franscisco AD. HIV/AIDS: Global Forum for
Health Research. The $10 / 90$ report on Health Research; 2001-2002. p. 146-9.

2. WHO Regional Health Report. HIV/AIDS. Health of Women in South-East Asia - a lifespan perspective; (Focus on women) 1998. p. 21-3.

3. AVERT. Indian HIV \& AIDS Statistics. Available at http://www.avert.org/aidsindia.html; Accessed on 19-01-2005.

4. Gangakhedkar RR, Bentley ME, Divekar AD, Gadkari D, Mehendale SM, Shepherd ME, et al. Spread of HIV Infection in Married Monogamous Women in India. JAMA 1997;278:2090-2.

5. Srikanth $P$, John $T J$, Jeyakumari $H$, Babu $P G$, Mathai D, Jacob M, et al. Epidemiological features of acquired immunodeficiency syndrome in southern India. Indian J Med Res 1997;105:191-7.

6. NACO Guidelines for the prevention of mother to child transmission of HIV available at http:// www.naco.nic.in/pmtct.html; Accessed on 19-012005

7. Bertolli J, St. Louis ME, Simonds RJ, Nieburg P Kamenga M, Brown C, et al. Estimating the timing of mother-to-child transmission of human immunodeficiency virus in a breast-feeding population in Kinshasa, Zaire. J Infect Dis 1996;174:722-6.

8. Miotti PG, Taha ET, Kumwenda NI, Broadhead R, Mtimavalye LA, Hoeven LV, et al. HIV Transmission Through Breastfeeding. JAMA 1999;282:744-9.

9. Kaur M, Mittal A, Kaur K. HIV infection and obstetrics. J Applied Med 1994:4:295-300.

10. Baveja UK. HIV Antibody Testing with special reference to HIV-1. HIV Testing Manual, Laboratory diagnosis, Biosafety and Quality Control, National AIDS Control Organisation: New Delhi; p. 45-67.

11. Kannangai R, Prabu K, Vincent AA, Vijayakumar TS, Sridharan G. Performance Evaluation of four different kits available in the Indian Market, for the rapid detection of HIV antibody. Indian J Med Microbiol 2003;21:193-5. 
12. Barbicci M, Repke JT, Chaisson RE. Routine Prenatal Screening for HIV Infection. Lancet 1991;337:709-1.

13. Dongaonkar D. Prevention of Mother to Child Transmission of HIV-1 Using Antiretroviral DrugZidovudine. J Obstet Gynecol Ind 2003;53:5637.

14. John TJ, Bhushan N, Babu PG, Sheshadri L, Balasubramanium N, Jasper $P$. Prevalence of HIV infection in pregnant women in Vellore region. Indian J Med Res 1993;97:227-30.

15. Ravikumar B, Sathiyasekaran BW, Sivaprakam $\mathrm{P}$, Shanmugasundaram V, Solomon S, Shirley C. Prevalence of HIV infection Among Antenatal Mothers in Chennai (Madras) India. J Obstet Gynecol India 1999;49:61-3.

16. Shyamala G, Kushtagi P, Madhushree VB. Seropositivity for Human Immunodeficiency Virus in Pregnancy in a Tertiary Care Hospital in SouthWest India. Indian Pract 2004;57:649-2.

17. Deshmukh AB, Damle AS, Anvikar AR. Epidemiology of Human Immunodeficiency Virus infection as a Sexually Transmitted Disease. Milestone, J Director Med Edu Res
(DMER) 2002;1:57-3.

18. Lakshmi V, Teja VD, Sudharani T, Subhadha K, Upadhyaya AC, Shantaram V. HIV Infection in a Tertiary Care Hospital - Clinical and Microbiological Profile. J Assoc Physic India 1998;46:363-7.

19. Jacob M, John TJ, George S, Rao PS, Babu $P G$. Increasing prevalence of human immunodeficiency virus infection among patients attending a clinic for sexually transmitted diseases. Indian $\mathrm{J}$ Med Res 1995;101:6-9.

20. Rao KB. HIV Infections in Pregnancy - A review. J Obstet Gynaecol India 1999;49:31-4.

21. Kapoor A, Kapoor A, Vani SN. Prevention of Mother to Child Transmission of HIV. Indian J Pediatr 2004;71:247-1.

22. Jackson JB, Musoke P, Fleming T, Guay LA, Bagenda D, Allen $M$, et al. Intrapartum and neonatal single dose nevirapine compared with zidovudine for prevention of mother-to-child transmission of HIV-1 in Kampala, Uganda: 18month follow-up of HIVNET 012 randomised trial. Lancet 2003;362:859-8.

Indian Journal of Medical Sciences is pleased to announce the launch of its website. The URL of the website is http://www.indianjmedsci.org.

The features of the site are:

- Free full text availability of articles in HTML as well as PDF

- Link to abstracts and full text from the cited references

- Link to PubMed abstracts of published articles by authors

- Link to related articles in PubMed

- Link from text of articles to various databases and search engines

- Facility to submit comments on articles

- Email notifications on new issue release

- Statistics of articles download and visits

- Structure based on OpenURL, DC Metadata and other international standards 